\title{
The Colonial Medical Service and the struggle for control of the Zanzibar Maternity Association, 1918-47
}

\author{
Anna Greenwood
}

British colonialists on Zanzibar frequently grumbled that its colourful demographic character was a particular headache to their administration. When the British formally established their administration in 1890 they encountered a 'distinctly urban, mercantile and cosmopolitan' island economy which had developed over centuries and was headed by Sultan Sayyid Ali bin Said Al-Busaid and his extravagant court. ${ }^{1}$ Zanzibar was home to a thriving merchant class of Arabs and Indians, as well as poorer members of these communities, co-existing alongside the majority African poor. ${ }^{2}$ Even British generalisations had to concede that this was far from the supposed blank canvas implied through rhetorical representations of the mainland Dark Continent. ${ }^{3}$ Forced to be sensitive to the existing political structures, the British ruled Zanzibar as a protected Arab state, leaving the Sultan as constitutional head until 1913 (and indeed as a figurehead until independence in 1963). Furthermore, they adapted their administration to the existing hierarchies on the island by retaining the Arab ruling caste and by staffing the lower ranks of their administration with 'mudirs' members of the local Arab elite - who acted in a similar role to British District Officers on the mainland. ${ }^{4}$ Despite its proximity to the African mainland, Zanzibar's distinctiveness was pronounced and it was regarded as given that it needed special and relatively subtle political management. This region was, according to one contemporary commentator, a 'huddled, unplanned block of Asia', where life was 'not African' and the ancient capital, Stone Town, was '[e]ssentially ... an Arab town'. ${ }^{5}$

Although Zanzibar was defined as one set of islands, it contained various well-established communities. Most were comprised of Africans of Bantu origin, but these were increasingly joined by Africans of various ethnic groups from the mainland. The next biggest group were immigrants from Arabia, principally from Muscat, Oman or 
Hadramaut. A further section of the population had ties to the Indian subcontinent, made up of Indians, Pakistanis and Goans - a religious mix of Moslems, Ismailis and Hindus. The situation presents a striking historical example of a colonial power having to formulate policies that were applicable to different, yet cohabiting, populations.

The ethnic diversity of the island posed particular challenges for the British medical authorities. Despite acting as the main quarantine station for Kenya, Tanganyika and Uganda, the hub of Stone Town was renowned for its disease-ridden port and overpowering stench. The islands were nicknamed 'Stinkibar' by David Livingstone in 1866, leading to routine associations with a whole gamut of public health problems. ${ }^{6}$ British medical control was hindered by the perplexing range of indigenous behaviour towards matters of health, making any blanket public health policy frustratingly difficult to conceive, apply and police. In Zanzibar 'Africa, Arabia and Asia seem to meet and blend', bemoaned one medical commentator in 1924, directly creating 'all kinds of sanitary questions ... in consequence'.

The case of the Zanzibar Maternity Association (ZMA) provides one example of the British negotiation of this racial diversity on Zanzibar. By showing that the Colonial Medical Service was increasingly unhappy to work with another healthcare provider on Zanzibar - in this case the majority Indian- and Arab-funded ZMA - we are given an instructive lens through which to examine the way colonial medical policy was sometimes selectively deployed. This shows, above all, how the British sought to manipulate their self-image in relation to the racial politics of the island, in ways that flexibly prioritised their own interests.

Despite the fact that that the ZMA had originally been a British idea, and irrespective of the Association's subsequent popularity and success, the Colonial Medical Service showed itself to be uninterested in supporting medical initiatives unless it was allowed to fully control and manage them. Although the ZMA filled a conspicuous gap within the healthcare provision offered by the Colonial Medical Service on Zanzibar, the British government was happy to fund and cooperate with it only if it could essentially run it as an adjunct part of the colonial medical department. When the Arab and Indian funders objected to this - at least wanting credit for their initiatives - the British were quick to disparage the ZMA and the recipients of its services, often in quite strong language. Surprisingly, the British eschewed, rather than embraced, the opportunity of working with rich local philanthropists, notwithstanding the potential of the situation to promote the magnanimity and cooperativeness of British imperial overlordship.

While the focus of this chapter is a maternity association, the issue is not birthing practices, or the development of colonial maternal health 
policy as such - this has been extensively explored in other writings about Empire. ${ }^{8}$ Rather, this example is chosen as an illustration of the way the Colonial Medical Service could be sometimes mistrustful about working beyond what it felt to constitute the remit of the State, whether that be with missionary clinics, schools or local charitable initiatives. The story of the tumultuous British relations with the ZMA illustrates how uneasy the British were about being eclipsed or even simply not credited with being the most important givers of formal medical care on the island. As the ZMA was supported mostly through Indian and Arab coffers, the British were nervous about the service the ZMA provided, even though they had no alternative government maternity care provision of their own to offer and even though the model of maternity care provided by the ZMA was broadly in accordance with Western biomedical principles in so far as it advocated precepts of Western hygiene and promoted the benefits of hospital care in some circumstances.

The case of the ZMA also shows how the British were prepared to elastically deploy racial arguments against their Indian and Arab colonial subjects to suit their needs. While in some situations it was regarded as appropriate to work with locals (for example by employing mudirs, or employing Indian Assistant and Sub-Assistant Surgeons within the colonial medical department; see Chapter Four), equally there were situations when cooperation was evidently deemed less desirable. ${ }^{9}$ The essential point seemed to be the necessity of decisive government control. If the Indians, Arabs or Africans were employed by the colonial state, even in relatively influential roles, the dominance of the British seemed safe. To cooperate with these groups on a more equal footing, particularly when they were the majority funders of an enterprise and argued for proportionate influence in its affairs - as was the case with the ZMA - was far less desirable.

This example highlights a rarely discussed area of colonial governance, although it ultimately makes no firm conclusion as to whether racial politics were an epiphenomenon or a determinant of colonial policy. What it does usefully show, however, is that while it is now universally accepted that the British were racist in their attitudes and actions towards their colonial subjects, also these attitudes could be subtly and selectively deployed adaptively and responsively to local situations. In colonial Africa, Africans were habitually portrayed as the least civilised race, the lowest rung in the racial hierarchy. But, as the case of the ZMA shows, when it suited their aims, the British characterised Indians and Arabs as far worse than the Africans, pinpointing them as the most primitive ethnic groups on the island and in need of reform. ${ }^{10}$ Indeed, ZMA archive files show that, where 
expedient, Africans were often praised as showing openness to change and reform, in contrast to the intransigent attitudes of their Indian and Arab counterparts.

One of the reasons put forward by the British as to why they were unhappy to support the ZMA was that members of the Arab and Indian communities principally claimed its services. This is intriguing. Although the ethnic diversity of Zanzibar had been established over centuries, and was acknowledged by the British in many of their other policies (such as the decision to allow Islamic law to function in tandem with colonial law on Zanzibar), somehow the British still felt that it was acceptable to insinuate that their medical services were principally directed at just some of their colonial subjects. In short, by complaining about the way the ZMA principally helped Indian and Arab communities, the British seemed to be implying that they held a preference to help black Africans, rather than the members of the Indian or Arab community. The reason for this seems evident: Indians and Arabs were perceived as providing the most tangible threats to British superiority. In the case of the struggles over the control over the ZMA it therefore suited Colonial Medical Service objectives to portray Indians and Arabs as untrustworthy sponsors - representatives of communities that were particularly susceptible to disease and that lacked personal hygiene.

\section{The Zanzibar Maternity Association and the British}

The ZMA was a quasi-autonomous charity founded in 1918 on the advice of three British officials, two of whom were government doctors: Mr Crofton, Dr Copland and Dr Curwen. The organisation was conceived as a means of supplying trained midwives to attend Asiatic, Arab and African women in their confinements. Although ZMA services briefly expanded to outlying rural areas in the early 1930s, these were never very successful and the ZMA principally catered for the multiethnic inhabitants of Zanzibar's thriving capital, known as Stone Town. As registrations of births on Zanzibar were unreliable, it is difficult to gauge how successful the ZMA was in real terms, although the yearly statistics show that attendances rose steadily throughout its existence, except for a dip in 1933, which was explained away as part of the worldwide Depression. ${ }^{11}$ The high point of its success was achieved in 1938, when as many as 75 per cent of all births taking place in Zanzibar Town were attended by ZMA midwives. ${ }^{12}$ An important feature of the service was that it did not insist on hospital care for expectant mothers and also aimed to provide culturally relevant services for the communities of Zanzibar Town via home visits. ${ }^{13}$ 
From the start the ZMA had a rather ambiguous status. It had been a British idea, but it was declared by a government officer as 'a private enterprise ... [without] the same permanence as a Government undertaking ${ }^{\prime} .{ }^{14}$ Crucially, it was not considered part of official colonial medical policy - to the extent that the founding of the ZMA was not mentioned in the government Annual Medical Report (AMR). ${ }^{15}$ While it was described as 'not a Government institution' it was also said to be 'under the Patronage of the Zanzibar Government', with the terms left sufficiently vague to allow the interpretation that both the British colonial government and the hereditary sultanate, which was also a patron of Association activities, had joint responsibility. ${ }^{16}$ Although ZMA leadership always comprised a British (often non-medical) official, ${ }^{17}$ it was not absorbed into the British colonial administration until 1947, principally because its reliance on external patronage would have been at risk if the British assumed dominance.

The British contributed an annual grant (initially 4,500 rupees ${ }^{18}$ ) towards the running of the ZMA and the rest of the Association was supported by private subscriptions and donations, as well as from the profits made from any fees charged to patients who could afford to pay (set at 75 shillings per case). ${ }^{19}$ Particularly prominent in funding the ZMA was the Wakf Commission (based on the ancient Islamic law of waqf), which oversaw the spending of Islamic endowments for the purposes of charity. ${ }^{20}$ This Commission was set up on Zanzibar by the British in 1905 to oversee the distribution of wakf, so this contribution was sanctioned by the British even if its sources were not British. ${ }^{21}$ Also highly significant in the funding profile were Tharia Topan, who controlled and distributed the inheritance of his forebear, the knighted Ismaili Indian merchant and Zanzibari philanthropist of the same name; and the Indian National Association, which paid for beds to be made available for Association mothers in the Mkunazini Hospital (in the days before the ZMA had its own hospital facility) and also paid the salary of the ZMA's European midwife, Miss Locket. ${ }^{22}$ From its inauguration, the different funding bodies represented in the ZMA's quarterly meeting General Committee struggled to gain ascendancy and to stipulate the ZMA's agenda. While the Indian and Arab representatives understandably wanted to make provision for their own communities, the British tended to advance the African cause, which they increasingly saw as their responsibility within the terms of the dual mandate.

Aside from the date of its foundation, a few other dates mark important points in the history of the ZMA and highlight the progressively acrimonious relations that developed between the Association and the Colonial Medical Service and peaked during the 1930s. In 1925 the 
Mwembeladu Maternity Home was opened as the institutional base for maternal welfare work. The home, 'built largely from funds provided by the Tharia Topan family', ${ }^{23}$ was also substantially funded $(30,000$ rupees (Rs)| by the Wakf Commission, with the internal furniture and fittings provided by the prominent Indian company Messrs Karimjee Jivanjee and Co. ${ }^{24}$ Although the British government was not the primary funder of this home, it did increase its annual grant to the ZMA from Rs 4,500 to Rs 7,500 when it opened, and agreed to supply free drugs and dressings for its patients. The first decade of Mwembeladu's existence, however, was characterised by struggles over its control and marked the beginnings of the distinct souring of relations between the British government and the ZMA. ${ }^{25}$ When the home opened in 1925 the British had assumed that it would be under the control of their medical department, ${ }^{26}$ but the majority members of the ZMA, who had secured funding for the building and its contents, naturally envisaged it as independent of British state control. By 1934 intransience by members of the ZMA on this issue meant that the British had to concede that 'what little control government had in the past has now been lost', and in 1937 the control of Mwembeladu was officially declared as being solely back in ZMA hands. ${ }^{27}$ This decisive move underlined ZMA preferences for independence and was conducted as part of a broader revision of the structure and remit of the ZMA, resulting in the new Reserved Articles of the Association of $1937 .{ }^{28}$

A period of particularly intense British criticism led up to this 1937 administrative overhaul. In 1932 the ZMA announced its hope to start a midwife-training programme, as a means of extending its services to the rural areas. It planned to recruit rural women for training at Mwembeladu and then let them return to their home communities to practise their skills. ${ }^{29}$ This scheme got off the ground in 1933 with the opening of seven rural centres, but it soon became apparent that the problems of the Depression and limited funding meant that the initiative was not viable unless external contributions could be found. The British, however, refused to help the ZMA in their scheme, a move which ensured its failure. ${ }^{30}$ Without British support, the ZMA had no option but to hand control over to the government, which promptly reversed its earlier opposition to the scheme and offered to take it over entirely from 1935. ${ }^{31}$ Immediately upon taking control, however, the medical department embarked upon a regional survey, damningly concluding that it was 'unfavourably impressed by these rural centres' and recommending that all but one should be closed down. ${ }^{32}$ To add insult to injury, the British government then announced that, as compensation for taking over the centre work from the Association, it would reduce its grant to the ZMA by Rs 600 a year, despite its intention to 
close down most of the newly acquired rural centres. ${ }^{33}$ This episode provides a striking example of the way the British used the financial pressures of the ZMA for their own advantage. They knew that the ZMA could not expand without their support and went so far as to financially punish the ZMA for its apparent lack of foresight. The bitter attitude of the British medical department preferred total absence of rural maternity services to exclusive provision by the ZMA.

Concurrently with this crisis in relations - and not entirely unconnected to it - there occurred a period of separate 'quarrels' between the ZMA and the British administration about the 'misapplication of funds' and arguments about 'general control and representation on the committee'. ${ }^{34}$ Particular attention was paid in these arguments to the dominant role played in the ZMA General Committee by Tharia Topan. The British government declared that it felt as if it had had 'a pistol held to its head by Tharia Topan' since his appointment to the committee in $1928,{ }^{35}$ because 'he felt he should have a larger say in matters concerning the Association than other members of the Committee' ${ }^{36}$ British dissatisfaction with Topan was so recurrent that eventually the ZMA, faced with the threat of alienating British funding altogether, was forced to negotiate a compromise with him, securing his retirement from their governing board. ${ }^{37}$

The 1937 new Reserved Articles of the Association were produced in reaction to this dissatisfaction over representation, financial mismanagement and long-brewing misunderstandings over administrative proprietorship of the Mwembeladu Home. The aim was to make the ZMA more transparent and administratively efficient and was a clear response to vocal British claims of financial incompetence, cumbersome bureaucracy and internal discord. ${ }^{38}$ Superficially, this bureaucratic clarification looked like an attempt to establish the charity's independence from the British government. Although British officials still presided on the committee, and the British government still financially contributed to its affairs, the ZMA officially declared itself to be 'no-longer under the control of the Medical Department and managed by its own committee'. ${ }^{39}$

In effect, this was to be the ZMA's final assertion of defiance and independence. Almost as soon as the Articles were enacted, the British began to actively pursue investigations into the financial dealings of the ZMA and to re-agitate for control over Mwembeladu. In 1939 direct accusations were made against the ZMA by the new colonial Medical Officer in charge, Dr Sydney Lee. Lee declared that ZMA funds for Mwembeladu were internally mismanaged, and also called into question the government's historic agreement with the ZMA to supply free drugs and dressings to the home. ${ }^{40}$ Outside the ZMA committee, 
Association members were suspicious of Lee's investigations, declaring that his actions were intended 'to prove that the government should take over the Home by bringing the Association into some disrepute' ${ }^{\prime}{ }^{41}$ Rumours circulated that 'there was little secrecy about the hope or intention of the Medical Department to take over this home' ${ }^{42}$

These prolonged investigations coincided with more general moves towards the regulation of colonial midwifery. The British government seized upon them as further support for its argument that the ZMA could function adequately only if it was run and policed by the Colonial Medical Service. The Central Midwives Board in the UK had been established in 1902, but during the 1940s it began to extend its regulatory framework for the training and conduct of midwives within the British Empire. Partly in response to this, in 1942 Medical Officer Violet Sharp introduced her new formal training scheme for midwives on Zanzibar - a clear snub to ZMA midwifery training initiatives which had been underway since the 1930s. Miss Locket, the ZMA chief midwife, was only too aware that tighter restrictions were to be introduced and saw the potential effects that this would have on the ZMA, which relied on illiterate local midwives trained via an apprenticeship system. Locket anxiously wrote to the ZMA president in 1943 that 'everything has now been completely changed', owing to the new provisions instituted by the Central Midwives Board in the UK, which were soon to be rolled out to the colonies. ${ }^{43}$ In effect, the British used their colonial power to undermine ZMA midwifery training activities by pointing out that they did not comply with international standards.

The succession of events was relatively rapid. By 1944 discussions were already underway for the ZMA presidency to be taken over by a British Medical Officer, and in 1947 - the year of Indian independence and a point when nervousness about colonial rule was at a high - the British government formally took over control of the ZMA, installing Dr J.C. Earl as president and severely limiting Indian and Arab representation. Significantly, Earl's first act as was to enact his Midwives Decree (no. 12) 1945, which he had personally drawn up himself, finally formalising midwifery provision and training on Zanzibar in accordance with British guidelines and standards. ${ }^{44}$ Tellingly, the British ultimately referred to colonial law and governance as their final lever to justify their dominance over the ZMA. Insistence that the ZMA's practices and training provision were not in accord with the stipulations of the British government as enshrined in the Central Midwives Board was the most powerful means by which the government could exert pressure on the ZMA. Against such legislative pressures, the ZMA had little option other than to capitulate. 


\section{Maternal health on Zanzibar}

The work of the ZMA and the tensions between it and the British government need to be understood in the broader context of colonial maternal health provision at that time. It is striking that the Colonial Medical Service was so antagonistic towards the ZMA, as no other formal provision for maternal welfare existed in Zanzibar under the government medical services. As the government itself admitted in 1928: '[b]eyond rendering all possible assistance to the Zanzibar Maternity Association, the Government medical staff has little time to give to this important branch of public health work' ${ }^{45}$ The ZMA provided the only organised maternal welfare work in the region, and yet the British were increasingly unprepared to cooperate with it. Over and beyond the local tensions, this perhaps demonstrated a more general nervousness about any organised social provision on the island outside government control.

The late arrival of government maternal and child welfare services in Zanzibar is somewhat of an anomaly in the region. This was partly because of Zanzibar's island status, which meant that, despite its strategic importance as the main port of entry for East and Central Africa, the Colonial Office tended to channel financial and personnel resources into its larger, more politically prominent territories on the mainland. Medical reports of the period all reiterated the ill-effects of the chronic lack of resources and constantly complained about the lack of personnel and the consequent inability to make any real inroads into either hospital-based or community-based healthcare provision. The low priority afforded to maternal healthcare on Zanzibar (no mention was made of maternal or child health in any AMR before $1922^{46}$ ) should be understood in this local context, but it was still enormously behind the rest of Empire; with discussions of colonial healthcare within contemporary textbooks devoting chapters to the centrality of structured maternity care within British possessions. ${ }^{47}$ In fact, maternity and child health within the colonies increasingly became a key topic for discussion from the interwar years onwards, reflecting similar preoccupations in the domestic sphere in Britain. ${ }^{48}$

Indeed, the lack of such healthcare provision on Zanzibar also frustrated the British medical administration. It was conventional throughout Empire for a Woman Medical Officer (WMO) to be appointed to oversee maternity and child welfare work and, from 1924, the British medical department on Zanzibar regularly lobbied the Colonial Office to have such a colonial servant posted to the island. ${ }^{49}$ It took twelve years, however, before Dr Violet Sharp was finally appointed in May $1936,{ }^{50}$ twenty-five years after Uganda, where the WMO position had 
been filled in 1911..$^{51}$ The Zanzibar Director of Medical Services, Leslie Webb, retrospectively explained away this discrepancy as being due to the comparative 'urgency' of the situation in Uganda, where syphilis was widespread, whereas the disease did 'not appear to be a major problem' in Zanzibar. ${ }^{52}$

Unsurprisingly, Dr Sharp's arrival did not bring any immediate change to the state of official maternal healthcare provision. When the chief medical advisor to the colonial officer, A.J.R. O'Brien, visited Zanzibar in 1938, he announced that he was 'displeased to find that Government undertook so little maternity work'. He also expressed his alarm at the ZMA arrangements at Mwembeladu Maternity Home. How could it be that the home was 'controlled by a Committee of 10 Indians or Goans, 3 Arabs, 1 African and 1 European' and yet had 'all expenses ... borne by the government' ${ }^{53}$ This complaint neatly encapsulates the fundamental anxieties of the British government. Although the British were unable to offer any alternative organised maternity provision on Zanzibar until the early 1940s, they were nevertheless extremely anxious about the work of the ZMA and what this might indicate in terms of the erosion of (their perceived) Western medical hegemony. Simply put, the medical department found it very difficult to support any healthcare facility that it could not absolutely control, regardless of the local needs it fulfilled or the popularity it enjoyed.

\section{Health discourses and Colonial Medical Service complaints about the ZMA}

At the heart of the increasingly problematic relations between the ZMA and the Colonial Medical Service lay the general assumption of European racial superiority, as demonstrated throughout Empire in the motives of the civilising mission. This construed the British role to educate and to reform indigenous populations and, in matters of health, paid particular attention to the alleged lack of hygiene and particular propensities towards disease of the 'unreformed' and pathological indigenes; a tendency which has been explored at length within the colonial medical literature. ${ }^{54}$ Quite naturally the Colonial Medical Service's attitudes on Zanzibar conformed to this general model, with medical reports frequently bemoaning that no amount of help or external improvements in matters of health would help indigenous people (including, in the context of Zanzibar, Arabs and Indians) if they were not prepared to help themselves. A short history of the ZMA, written by an anonymous British official, explicitly reminisced on the regrettable predominance of old-fashioned birthing practices that existed in 1918: 
Prior to its inception the populace was dependent on the services of untrained and ignorant women whose unclean habits and ingrained prejudices and customs were responsible for much suffering and mortality among lying-in women and new-born children. ${ }^{55}$

Typically, high mortality and propensity towards disease were explained in terms of indigenous culpability through resistance to change. Similarly, the 1927 AMR of the British government declared that:

Natives of a tropical country have many and varied parasites to contend with. Their past traditions are those of apathy and indifference and these can only be gradually overcome. Nothing dramatic can therefore be expected, but rather a gradual improvement spread over the course of years. ${ }^{56}$

Ideas specifically connecting maternal health with flawed and unhygienic behaviour were particularly marked. The need for maternal health provision was presented as one of the most important challenges because indigenous women were generally considered to be especially superstitious influences within the social fabric. As one medical report warned: ' $[\mathrm{t}]$ he women to a much greater extent than the men are imbued with superstition and it is they who insist on charms and incantations and delay calling in skilled medical assistance until too late'.${ }^{57}$ The declared purpose of the ZMA was to offer a modern alternative to traditional models of maternal health, counteracting, for example, the influence of:

untrained dayas whose ignorance, prejudices and unhygienic methods were responsible for much suffering and mortality amongst lying-in women and new-born children. Shocking stories were current of methods employed. [Dr] Curwen told me of a case in which a piece of rope was tied round the neck of a half-born baby and a stone attached to aid delivery. ${ }^{58}$

The self-proclaimed ardency of the ZMA to bring clean and safe modern practices to traditional communities gave it an affinity with the biomedical priorities of the Colonial Medical Service, which was also preoccupied with stamping out superstition and enlightening its colonial subjects to the benefits of modern Western medical techniques. However, during times of conflict between the two groups, the British preferred to distance themselves from the funders of the ZMA, often making derogatory comments against the health habits and management acumen of the Indian, and, most damningly, the Arab, populations of Zanzibar. Such negative rhetoric was used to justify attitudes towards, and even sanctions against, these particular groups. ${ }^{59}$ These colonial discourses were intriguingly out of kilter with customary racial generalisations, which tended to place the influential Arab and 
Indian elite far higher than Africans in terms of social status - indeed the Arabs themselves were keen to stress the huge gulf between their 'civilised' Islamic culture and the 'barbarous' African one. ${ }^{60}$ British files on the ZMA reveal that racial stereotypes were applied rather flexibly (within the overall paradigm of European superiority) to suit the circumstances presented by different colonial situations.

The ZMA management stressed that the Association did not 'confine its activities to any one sect' and was a 'social service non-racial in character', but conflicts about racial priorities nonetheless permeate internal struggles over its remit during the 1930s. ${ }^{61}$ As the Association was mainly funded from Indian and Arab sources, it was primarily concerned with helping mothers within these local communities; certainly they were by the far the largest groups cited in the ZMA's annual reports as using its midwives. ${ }^{62}$ Even this provision was sometimes contested, however, with various religious and ethnic subgroups of the Arab and Indian communities sporadically complaining that funds were not being targeted at the specific communities for which they had been intended. ${ }^{63}$ Theoretically at least, the ZMA was supposed to be equally committed to helping Africans, and the apparent lack of even-handedness in pursuing this point (not entirely borne out by the figures, which showed gradually increasing African attendances ${ }^{64}$ ) was the one which the British seized upon and repeatedly used to denounce the ZMA for its bias in favour of the Arab and Indian communities of Zanzibar Town. ${ }^{65}$

At the same time, the British frequently used opportunities to criticise the health habits of the Arab and Indian communities, characterising them as far from redemption in matters of health and hygiene, and hence calling into question the utility and effectiveness of the ZMA. This was an inversion of the usual British ordering of indigenous civilisations, but it crucially served British purposes in that it tarnished the reputation of the group that was giving the government the most competition (with all the implied political threats that this entailed) on the islands. A snippet from the AMR 1921 is indicative:

It is to be regretted that the average poor-class Indian is utterly deficient in any sense of hygiene. To shut out all light and air, to crowd together, to spit freely and constantly all over the place, whether indoors or out, seem to be ingrained habits with them. They have a complete disregard of sanitation laws for the public welfare and are quite prepared to hide cases of infectious disease if they think that its notification to the authorities will cause them inconvenience, as was shown in the case of Small-pox concealed by Indians in the bazaars. The natives, too, are equally fond of stuffiness, overcrowding and expectoration, and, although when they live in their own mud and wattle huts they make 
some attempt at cleanliness, they soon lose this when they crowd into the already crowded bazaars. ${ }^{66}$

A similar conclusion was reached in an assessment of the health and hygiene of school children: '[a]s regards cleanliness, there is no doubt that the Africans and Comorians are the cleanest, and the Arabs are cleaner than the Indians'. The British medical author went on to specify that '[d]efects of vision are commonest in Indians and Arabs, as are defective teeth' ${ }^{67}$ Time and again the same negative rhetoric related matters of poor hygiene, with the 'Arab, Shihiri and Comoro communities' claiming them to be 'the most backward in realizing the benefits of Western methods' ${ }^{68}$

It might be thought that if the British genuinely felt that the Arab and Indian communities of Zanzibar were most in need of health improvements, these sectors would be thought the most deserving or at least the most worthy targets of reform - but rather, the British seemed to use these denunciatory images to justify and help reiterate their exclusive orientation towards the African communities. This points to the crux of the issue, clearly summarised in a letter of 1942:

[The] Government is primarily concerned with the training of African Midwives for work in rural areas amongst Africans; whereas the Association is concerned primarily in providing a Town service for Indian and Arab people, though naturally the services of the Association's midwives are not denied to Africans. The Association [therefore] caters for an unavoidable Racial [sic capitalisation] prejudice ... ${ }^{69}$

If the British were going to help indigenous groups via their medical department (as was becoming the colonial expectation by the 1920s), they wanted to be seen to be helping Africans. This emphasis was quite explicit. From the time the ZMA was founded in 1918 the British government made it clear that its proportion of the ZMA grant was only 'intended to cover free treatment for African mothers' and that other communities were to provide services for their own ethnic groups. ${ }^{70}$ Again when the British government increased its grant in aid to the ZMA, in the light of the increased costs associated with the opening of the Mwembeladu Maternity Home, it reiterated to the general meeting that its grant was 'given only in respect of free services to poor natives'. ${ }^{71}$ Thus community parochialism - but particularly British antipathy and apprehension of Indian and Arab prosperity and local influence - undermined the ultimate effectiveness of the ZMA. The Honourable Chief Secretary of the ZMA (a British representative, but not of the medical department) level-headedly summarised the situation as follows in 1937: 
All of you know how the Association started - to meet a very serious need in the town - and it would be deplorable if the public spirit and efforts made in the earlier days were to be defeated by any failure to come to some workable arrangement for carrying on the work of the Association. Naturally the communities who are chiefly concerned ask for an effective say in the affairs of the Association, but at the same time as a large annual grant of public funds is involved it is essential that the Government should also be in a position to ensure that the money is applied effectively. It is the difficulty of reconciling these two principles which has led to a good deal of trouble. ${ }^{72}$

Worries about excessive Indian and Arab representation in the ZMA also found their resonance in downbeat British comments about the midwifery services provided. It was felt that 'the pay of midwives who attend the non-African population of the Town is ... extremely high', not least as it was 'in excess of the maximum salary of a government European Nursing Sister, and is out of all proportion to services rendered ${ }^{\prime}{ }^{73}$ Zanzibar was characterised by members of the British medical administration as not having the necessary 'raw material' in terms of young women to be trained in midwifery work. As government Medical Officer Dr Leslie Webb pointed out in 1934: 'A sine qua non of a successful midwifery service is a staff of competent and respectable midwives. ${ }^{174}$ Any sort of rural maternity provision, he argued, had to provide culturally relevant midwifes, which in the rural areas of Zanzibar meant they should be 'a village Swahili'.$^{75}$ It is not that Webb was wrong in characterising the needs of rural communities thus, but rather, that the British continually emphasised the African cause. In stark contrast, the ZMA felt that it could not really invest too much effort in training African midwives, because the majority Arab and Indian women would 'object to the presence of pupil midwives at their accouchements, especially if the midwife is African' ${ }^{76}$

The British, in theory at least, were much more concerned with providing rural healthcare for Africans than healthcare for the cosmopolitan (and politically active) communities of Zanzibar town, but obviously this was a selective and inconsistent claim. When the Colonial Medical Service had an opportunity to cooperate with the ZMA in its ambitions to establish a network of rural maternity health centres in 1933, the British declined to become involved because they were unable to dominate the rural expansion programme.

The British denial of their responsibility towards the Indian and Arab communities of Zanzibar in their dealings with the ZMA betrays a curious tension in colonial circles. In other realms the British actively pursued a policy of cooperation with the island's Arab elite, who were acknowledged as vital to the island's economy and political stability. 
The struggles for control of the ZMA therefore highlight some of the internal dynamics of the colonial encounter which are rarely explored: namely the racial hierarchies constructed by the British towards the heterogeneous populations of the island. Of course European health was the tantamount concern, but in terms of the indigenes it was Africans, from the British perspectives, that were most deserving of their help and charity.

\section{Conclusion}

At one level this account reveals a very sorry local story of thwarted good intentions. As Colonial Medical Officer Dr Sydney Lee ruefully admitted in a private letter (a rather bitter irony, considering the trouble he has directly caused the ZMA through his allegations against it): 'I find the whole history of the Zanzibar Maternity Association, Home, Dispensary and Rural Centres most depressing reading as it is simply an account of how excellent intentions were wrecked by faction fighting. ${ }^{177}$ From another perspective, this case provides an appealing local example of the role played by networks of neighbourhood patronage in building and sustaining a competing organisation of healthcare, supplementing and extending historical accounts of indigenous 'resistance' to colonial medical interventions. ${ }^{78}$

In a broader context, however, this study shows the highly manipulative and selective way the British applied their policies of health. This in turn reveals the way colonial governance embodied elements of stagecraft - ultimately always serving a broader racial-political agenda. The Colonial Medical Service had been trying to 'facilitate the acquisition of ... control' of the ZMA since the significance of its contribution to the care of maternal health in Zanzibar Town became apparent with opening of the Mwembeladu home in $1925 .{ }^{79}$ Clearly, to the directors of the Colonial Medical Service issues of control and dominance were more important than ideals of medical philanthropy. What is more, in justifying their withdrawal of support for the ZMA in the late 1920s and 1930s, the British used various methods to undermine its reputation. They criticised its management committee, they condemned its rural health initiatives and they discredited its midwife training programmes. Furthermore, they openly criticised the ZMA for principally supporting Indian and Arab women, seemingly oblivious to the implication that colonial medical services were principally for African populations.

Events within the ZMA's short history provide an opportunity to unravel the different British approaches towards an ethnically heterogeneous society. Although it was the majority African poor who were 


\section{BEYOND THE STATE}

considered the least cultured in both British and Arab discourses, it was the Arabs and Indians who were revealed to be the most problematic within the official British stance towards the ZMA's approach to health reform. In its most simple terms this selective bias undermined Arab and Asiatic ambitions for the ZMA and suited British ambitions over its control. When the hegemony of state medicine was threatened, the British were prepared to manipulate their response so as to protect themselves from any competition.

\section{Notes}

1 Abdul Sheriff, 'The Spatial Dichotomy of Swahili Towns: The Case of Zanzibar in the Nineteenth Century', Azania, 67, 2002, pp. 63-81, at p. 63

2 Trading wealth was based on a prosperous dhow trade in spices and ivory (and to 1897, in slaves). See Erik Gilbert, Dhows and the Colonial Economy in Zanzibar: 1860-1970, Oxford, James Currey, 2004; Abdul Sheriff, Slaves, Spices and Ivory in Zanzibar: Integration of an East African Commercial Empire into the World Economy, 1770-1873, London, James Currey, 1987

3 Patrick Brantlinger, 'Victorians and Africans: The Genealogy of the Myth of the Dark Continent', Critical Inquiry 12, 1985, pp. 166-203

4 Jonathon Glassman, 'Slower than a Massacre: The Multiple Sources of Racial Thought in Colonial Africa', American Historical Review, 109, 2004, pp. 720-54, at p. 734

5 R. Coupland, 'Zanzibar: an Asiatic Spice Island, Kirk and Slavery, The Times, 5 October 1928, p. 15

6 David Livingstone, Last Journals, 1866-88, quoted in Andrew Balfour and Henry Harold Scott, Health Problems of the Empire: Past, Present and Future, London, W. Collins Sons and Co., Ltd., 1924, p. 97

7 Scott, Health Problems of the Empire, 1924, p. 95

8 Denise Roth Allen, Managing Motherhood, Managing Risk: Fertility and Danger in West Central Tanzania, Ann Arbor, University of Michigan Press, 2002; Valarie Fildes, Lara Marks and Hilary Marland (eds.), Women and Children First: International Maternal and Infant Welfare, 1870-1945, London, Routledge, 1992; Sarah Hodges, Contraception, Colonialism and Commerce: Birth Control in South India, 1920-1940, Aldershot, Ashgate, 2008; Michael Jennings, "“A Matter of Vital Importance": The Place of Medical Mission in Maternal and Child Healthcare in Tanganyika, 1919-39', in David Hardiman (ed.), Healing Bodies, Saving Souls: Medical Missions in Asia and Africa, Amsterdam and New York, Rodopi, pp. $227-50$

9 For the neglected history of Indian doctors in East Africa see Anna Greenwood and Harshad Topiwala, Indian Doctors in Kenya: The Forgotten Story, 1895-1940, London, Palgrave Macmillan, 2015

10 There is a long history of generalisation about the common traits of ethnic groups. See Nicholas Hudson, "From "Nation" to "Race": The Origin of Racial Classification in Eighteenth-Century Thought', Eighteenth-Century Studies, 29, 1996 , pp. 247-64, at p. 249

11 'Appendix IV Fifteenth Annual Report of the Zanzibar Maternity Association for the Year Ending 31st December 1933', in Zanzibar Protectorate, Annual Medical Report, 1933, Zanzibar, Government Printer, 1934, pp. 77-82, at p. 77

12 Zanzibar National Archives (ZNA) AJ/29/248 Twentieth Annual Report of the Zanzibar Maternity Association for the Year Ending 31st December 1938, p. 2

13 ZNA AB/2/259 Letter from P.P. Balsara, Honorary Secretary, ZMA to Chief Secretary [no date, c. Spring, 1942] 
14 Richard Hayes Crofton, Zanzibar Affairs, 1914-1933, London, Francis Edwards, 1953, p. 18

15 Zanzibar Protectorate, Annual Medical Report, 1918, Zanzibar, Government Printer, 1920. The ZMA was first mentioned in government AMRs in 1922 and thereafter short supportive statements appeared annually until 1930. Between 1923 and 1933 the annual report of the ZMA was published as an appendix to the governmental annual report. After 1933, notably less mention of the ZMA is made in the annual reports, indicating an official distancing from Association affairs and an increasing desire to see its own maternity initiatives as separate.

16 ZNA AB/2/259 Letter Dr Leslie Webb to Honorary Chief Secretary 29 July 1935. On establishment of the ZMA in 1918 both the acting British resident and the sultan were joint patrons. Hayes Crofton, Zanzibar Affairs, p. 15

17 Before 1928 the president was usually the highest-ranking medical official on the island, after that time, presidents included S.B.B. McElderry, of the Colonial Agricultural Service and W. Hendry, of the Colonial Education Service.

18 Zanzibar Protectorate, Annual Medical Report, 1922, Zanzibar, Government Printer, 1923, p. 7

19 Although it was said that fees actually averaged around 56 shillings per case when remissions and exemptions were considered. ZNA AJ/29/248 Eighteenth Annual Report of the Zanzibar Maternity Association for the Year Ending 31st December 1936

20 The Wakf Commission briefly suspended its grant between 1922 and 1925, however. ZNA HD/10/17 Sixth Annual Report of the Zanzibar Maternity Association for the Year Ending 31 December 1924. Spellings of 'wakf' varied, sometimes being 'waqf'.

21 Laura Fair, Pastimes and Politics: Culture, Community, and Identity in Postabolition Urban Zanzibar, 1890-1945, Athens, OH and Oxford: Ohio University Press and James Currey, 2001, p. 123

22 ZNA AB/2/259 Zanzibar Official Gazette, 14 July 1928

23 ZNA AJ/29/248 Report of Meeting Held on 9 January 1937 to Discuss the Draft Articles of the Association of the Zanzibar Maternity Association, p. 2

24 ZNA AB/2/259 Letter from Leslie Webb to Honorary Chief Secretary, 29 July 1935

25 Struggles for Mwembeladu also fit in with broader struggles of the British government, via the Wakf Commission, to privatise wakf property. Fair, Pastimes and Politics, p. 124

26 Hayes Crofton, Zanzibar Affairs, p. 17

27 ZNA AB/2/259 Letter from Leslie Webb to Honorary Chief Secretary, 29 July 1935

28 ZNA AJ/25/3 Reserved Articles of the Association, 1937

29 'Appendix IV Fourteenth Annual Report of the Zanzibar Maternity Association, for the Year Ending 31st December 1932', in Zanzibar Protectorate, Annual Medical Report, 1932, Zanzibar, Government Printer, 1933, pp. 71-4, at p. 72

30 ZNA AB/2/259 Letter from Leslie Webb to Honorary Chief Secretary 9 October 1934

31 Zanzibar Protectorate, Annual Medical Report, 1934, Zanzibar, Government Printer, 1935, p. 30

32 ZNA AB/2/259 Letter from Dr Leslie Webb to Honorary Chief Secretary 19 September 1934. The final home was recommended to be closed down two years later, in 1936. ZNA AB/2/259 Memo Dr Leslie Webb to Honorary Chief Secretary 26 November 1936

33 ZNA AB/2/259 Letter from Dr Leslie Webb to Honorary Chief Secretary 19 September 1934

34 ZNA AJ/29/248 Letter from Acting Provincial Commissioner to Chief Secretary, Zanzibar, 4 May 1939

35 ZNA AB/2/259 Letter from Dr Leslie Webb to Honourable Chief Secretary [no date c. October/November 1936]

36 ZNA AB/2/259 Letter from Dr Leslie Webb to Honourable Chief Secretary, 29 July 1935

37 ZNA AJ/29/248 Report of Meeting Held on 9 January 1937 to Discuss the Draft Articles of the Association of the Zanzibar Maternity Association, p. 2 


\section{BEYOND THE STATE}

38 ZNA AJ/25/3 Reserved Articles of the Association, 1937

39 Zanzibar Protectorate, Annual Medical Report, 1937, Zanzibar, Government Printer, 1938, p. 37

40 ZNA AB/2/259 Letter Dr Lee to Chief Secretary, 12 June 1939

41 ZNA AJ/29/248 Letter from Acting Provincial Commissioner to Honourable Chief Secretary, 17 June 1939

42 ZNA AJ/29/248 Letter from Acting Provincial Commissioner to Honourable Chief Secretary, 17 June 1939

43 ZNA AJ/29/248 Letter from Miss B.J. Locket to Mr J. O'Brien, President, ZMA, 9 April 1943

44 ZNA AJ/29/248 Minute Dr J.C. Earl to Honorary Chief Secretary, 5 February 1944. See also ZNA AJ/29/248 Zanzibar Maternity Association, Minutes of the Meeting of the Executive Committee, 9 June 1947

45 Zanzibar Protectorate, Annual Medical Report, 1928, Zanzibar, Government Printer, 1929, p. 38

46 Zanzibar Protectorate, Annual Medical Report, 1922, p. 4

47 Balfour and Scott, Health Problems of the Empire, pp. 323-32

48 Margaret Jones, Health Policy in Britain's Model Colony: Ceylon (1900-1948), New Delhi, Orient Longman, 2004. Although Anna Davin has argued that British interest in maternal and child health in Britain's imperial possessions began around 1900. Anna Davin, 'Imperialism and Motherhood', in Frederick Cooper and Ann Laura Stoler (eds.), Tensions of Empire: Colonial Cultures in a Bourgeois World, Berkeley, University of California Press, 1997, pp. 87-151, esp. pp. 93-7

49 Zanzibar Protectorate, Annual Medical Report, 1924, Zanzibar, Government Printer, 1925, p. 42-3; see also, Zanzibar Protectorate, Annual Medical Report, 1925, Zanzibar, Government Printer, 1926, p. 31

50 ZNA AJ/27/705 Personnel File: Dr Violet Ruth Sharp. Sharp retired when she married in 1942, and was succeeded in 1943 by Dr Elizabeth Harrison. See ZNA AJ/27/596 Personnel File: Dr Elizabeth Nora Harrison

51 Dr Muriel Robertson. See Anna Crozier, Practising Colonial Medicine: the Colonial Medical Service in British East Africa, London, I.B. Tauris, 2007, p. 98. A discussion is also included here of WMOs in Kenya, Uganda and Tanzania more broadly. For the development of maternal health services in Nigeria see Deanne van Tol, 'Mothers, Babies, and the Colonial State: The Introduction of Maternal and Infant Welfare Services in Nigeria, 1925-1945', Spontaneous Generations, 1, 2007, pp. 110-31

52 ZNA AB/2/259 Letter from Dr Leslie Webb to Honorary Chief Secretary, 23 October 1934

53 ZNA AB/2/259 Letter from Dr J. Lee to Chief Secretary, ZMA, 11 July 1939

54 Warwick Anderson, 'Excremental Colonialism: Public Health and the Poetics of Pollution', Critical Enquiry, 21, 1995, pp. 640-69; Warwick Anderson, Colonial Pathologies: American Tropical Medicine, Race and Hygiene in the Philippines, Durham, NC, Duke University Press, 2006; Anna Crozier, 'Sensationalising Africa: British Medical Impressions of Sub-Saharan Africa 1890-1939', Journal of Imperial and Commonwealth History, 35, 2007, pp. 393-415; Megan Vaughan, Curing Their Ills: Colonial Power and African Illness, Cambridge, Polity Press, 1991. This list is far from exhaustive.

55 'Zanzibar Maternity Association', Zanzibar Official Gazette (Supplement), 14 July 1926

56 Zanzibar Protectorate, Annual Medical Report, 1927, Zanzibar, Government Printer, 1928, p. 7

57 Zanzibar Protectorate, Annual Medical Report, 1930, Zanzibar, Government Printer, 1931, p. 5

58 Hayes Crofton, Zanzibar Affairs, p. 15

59 Other examples of British selective policy making towards the different categories of colonial subjects on Zanzibar can be found in Geoffrey Ross Owens, 'Exploring the Articulation of Governmentality and Sovereignty: The Chwaka Road and the Bombardment of Zanzibar', Journal of Colonialism and Colonial History, 8, 2007, 
pp. 1-55; Friedhelm Hartwig, 'The Segmentation of the Indian Ocean Region. Arabs and the Implementation of Immigration Regulations in Zanzibar and British East Africa', in Jan-Georg Deutsch and Brigitte Reinwald (eds.), Space on the Move. Transformations of the Indian Ocean Seascape in the Nineteenth and Twentieth Century, Berlin, Klaus Schwarz Verlag, 2002, pp. 21-35

60 Jonathon Glassman, 'Sorting out the Tribes: The Creation of Racial Identities in Colonial Zanzibar's Newspaper Wars', Journal of African History, 41, 2000, pp. 395-428

61 ZNA AJ/29/248 Letter from Acting Provincial Commissioner to Chief Secretary, Zanzibar, 4 May 1939

62 Zanzibar Protectorate, Annual Medical Report, 1922, p. 7; ZNA AJ/29/248 Nineteenth Annual Report of the Zanzibar Maternity Association for the Year Ending 31 December 1937, pp. 1-2

63 E.g. in 1936 the Hindu Mandal ceased its contribution to the ZMA because it wanted its money to support only members of the Hindu community, except those of the Bhattia sect - a distinction which proved almost impossible to police. ZNA AJ/29/248 Eighteenth Annual Report of the Zanzibar Maternity Association for the Year Ending 31st December 1936

64 ZNA AJ/29/248 Nineteenth Annual Report of the Zanzibar Maternity Association for the Year Ending 31st December 1937, pp. 1-2

65 ZNA AJ/29/248 Zanzibar Maternity Association Jan 1937-June 1947, Letter from Provincial Commissioner to Chief Secretary, 21 October 1942. This should also be seen as part of a growing nationalist debate on the Arab elites on Zanzibar (Arab Association founded 1911). Even though this group did not directly speak in explicitly racial terms, it did mobilise a polemic of ethnic exclusionism that sought to favour urban Arabs over Africans of mainland origin. Glassman, 'Slower than a Massacre', p. 236

66 My emphasis: Zanzibar Protectorate, Annual Medical Report, 1921, Zanzibar, Government Printer, 1922, pp. 28-9

67 Zanzibar Protectorate, Annual Medical Report, 1921, p. 33

68 Zanzibar Protectorate, Annual Medical Report, 1923, Zanzibar, Government Printer, 1924, p. 80

69 ZNA AJ/29/248 Zanzibar Maternity Association Jan 1937-June 1947, Letter from Provincial Commissioner to Chief Secretary, 21 October 1942

70 ZNA AB/2/259 Letter from Dr Leslie Webb to Honorary Chief Secretary, 29 July 1935

71 ZNA AB/2/259 Letter from Dr Leslie Webb to Honorary Chief Secretary, 29 July 1935 , my emphasis.

72 ZNA AJ/29/248 Report of Meeting Held on 9th January 1937 to Discuss the Draft of Articles of the Association of the Zanzibar Maternity Association, pp. 1-2

73 ZNA AB/2/259 Letter from Dr Leslie Webb to Honorary Chief Secretary, 19 September 1934

74 ZNA AB/2/259 Letter from Dr Leslie Webb to Honorary Chief Secretary, 23 October 1934

75 ZNA AB/2/259 Letter from Dr Leslie Webb to Honorary Chief Secretary, 23 October 1934

76 ZNA AJ/12/35 Memo from Dr W.M. Lewis to SMO, 15 July 1942

77 ZNA AB/2/259 Letter from Dr S.W. Lee to Honorary Chief Secretary, 28 April 1939

78 David Arnold, Colonizing the Body: State Medicine and Epidemic Disease in Nineteenth-Century India, Berkeley, University of California Press, 1993

79 ZNA AB/2/259 Letter from Dr Leslie Webb to Honorary Chief Secretary, 7 July 1934 